\title{
Life Threatening Rupture of A Superficial Temporal Artery Aneurysm Presenting with Scalp Hematoma - A Rare Presentation
}

\author{
Sunil Munakomi* and Pramod Chaudhary \\ Department of Neurosurgery, College of Medical Sciences, Nepal
}

Submission: January 27,2017; Published: May 24, 2017

*Corresponding author: Sunil Munakomi, Department of Neurosurgery, College of Medical Sciences, Nepal, Email: sunilmunakomi@gmail.com

\begin{abstract}
Herein we report a rare case in a sixty year old lady who presented in hypotensive state with scalp hematoma following rupture of a traumatic aneurysm in a frontal branch of superficial temporal artery. After resuscitation she was undertaken for invasive angiography that revealed the aneurysm. The wound was excised and wound primarily closed. The lady made an uneventful recovery.

Keywords: Trauma; Aneurysm; Hematoma
\end{abstract}

\section{Introduction}

Traumatic aneurysm of superficial temporal artery (STA) is a known entity [1]. However, its presentation as life threatening scalp hematoma following its rupture is a rare epiphenomenon. Herein, we report one such case in a 60 year lady and discuss the management undertaken in the same.

\section{Case Report}

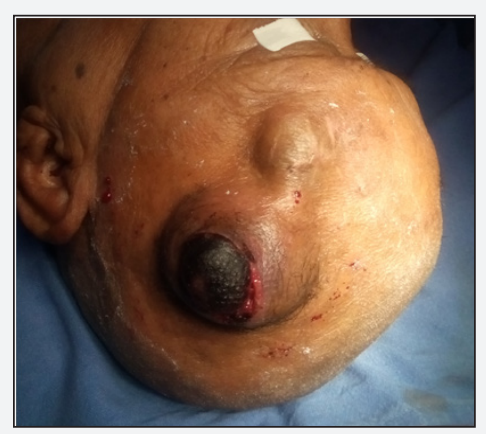

Figure 1: Scalp hematoma with the black crater on its top.

A 65 year old lady was brought to the emergency department in the College of Medical Sciences with a history of sudden onset bleeding and swelling on her scalp following a trivial fall at home (Figure 1). The patient was hypotensive at presentation with initial blood pressure of $60 / 40 \mathrm{~mm}$ of mercury. She was timely resuscitated. Initial lab investigation revealed hemoglobin of only $4.5 \mathrm{gm} \%$. She was therefore adequately transfused blood. Local examination revealed a scalp swelling in the left frontal region of approximately $6 \times 5 \mathrm{~cm} 2$ with a black crater on its top. There was no ongoing bleed. There was no bruit audible over the swelling or presence of any abnormal dilated vessels surrounding the lesion. There was however a linear scar in the vicinity of the swelling which the patient related to a fall injury she sustained eight months prior. The patient denied similar swelling elsewhere. The patient did not have significant past medical and surgical illnesses. She was not on any medications on a long term basis. There was no history of spontaneous epistaxis, ecchymosed or gum bleeding.

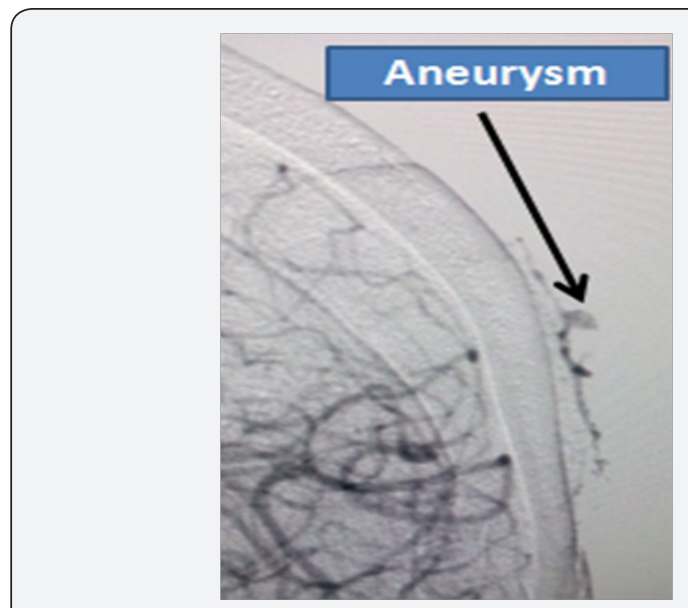

Figure 2: Angiography revealing aneurysm in the superficial temporal artery territory.

After the patient was hemo-dynamically stable, we performed invasive angiography that revealed an aneurysm in the STA territory (Figure 2). No other vascular abnormalities 
were seen. The patient and her relatives were thoroughly counseled regarding the disease condition and were advised for surgery.

The lesion was excised with clear healthy margins (Figure 3 ). The wound was closed primarily. Patient made an uneventful recovery and was discharged on the third post operative day. Histopathology did not reveal any vascular abnormalities. The patient has been on regular follow up.

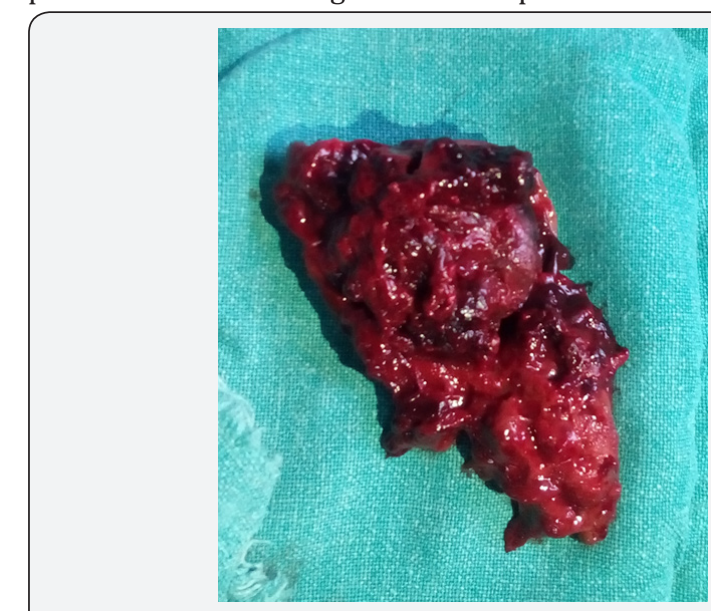

Figure 3: Excised lesion.

\section{Discussion}

STA aneurysm occurs mostly following blunt trauma due to the superficiality of its location [2]. Other causes include penetrating injuries, iatrogenic causes such as skull tractions and sometimes contact sports [3-5].

The main epicenter for the occurrence of the lesion is at the origin of the frontal branch of the STA wherein it traverses from the temporalis to the frontalis muscle but is tethered to the underlying fascia [6]. Presence of loose tissue in the scalp allows its growth and propensity for its subsequent rupture.

The time lapse from the trauma to the detection of the lesion is varying from days to 6 weeks in most of the cases [7]. The patients usually present with history of slowly progressive swelling with pulsating headache [8]. Pulsatile nature may be paradoxically absent if there in spontaneous thrombosis within the aneurysm [9]. Very few patients may present with cosmetic issues. Most often audible bruit will be heard over the lesion.

There are several methods mentioned so as to diagnose the condition [10]. Color Doppler ultrasound may be used in cases of pulsatile lesions. Computed tomography and magnetic resonance imaging, though noninvasive, cost factor is the main limiting issue for their routine use. In difficult cases like ours, wherein there was a rupture with huge scalp hematoma, invasive angiography has a place to correctly diagnose the condition.

However, there are risks adherent with it. It may have additional benefits in endovascular obliteration with uses of coils, thrombin or N Butyl C Acrylate (NBCA) in few selected cases [6]. Management of this entity diverse from conservative management, ultrasound guided temporary proximal occlusion of the STA trunk, endovascular and finally surgical excision of the lesion [11].

Intervention for this condition is justified because of the cosmetic issue and the risk of hemorrhage. Surgical excision is the preferred modality with proximal and distal ligation of the main trunk and excision of the aneurysm.

Our case is unique in many ways. Firstly, it was involving the frontal branch of the superficial temporal artery. Secondly, it presented 8 months after the history of trauma sustained to the head. Thirdly, its presentation as a life threatening bleeding episode as a scalp hematoma has not been previously reported.

\section{Conclusion}

This case report highlights the importance of accounting the fact that superficial temporal artery aneurysm can present months later the ictal head injury with life threatening scalp hematoma following its rupture. The timely intervention of this entity is therefore justified.

\section{References}

1. Lee HS, Jo KW, Lee SH, Eoh W (2010) Traumatic Pseudo aneurysm of the Superficial Temporal Artery due to Gardner Traction. Journal of Korean Neurosurgical Society 48(3): 291-293.

2. Han K, Borah GL (1996) Pseudo aneurysm of the anterior superficial temporal artery. Ann Plast Surg 37(6): 650-653.

3. Johnston KW, Rutherford RB, Tilson MD, Shah DM, Hollier L, et al. (1991) Suggested standards for reporting on arterial aneurysms. Subcommittee on Reporting Standards for Arterial Aneurysms, Ad Hoc Committee on Reporting Standards, Society for Vascular Surgery and North American Chapter, International Society for Cardiovascular Surgery. J Vasc Surg 13(3): 452-458.

4. Murakami M, Kakita K, Hosokawa Y (2003) Ruptured traumatic aneurysm after trivial injury mimicking acute spontaneous subdural hematoma-case report. Neurol Med Chir, Tokyo, 43: 130-133.

5. Quereshy FA, Choi S, Buma B (2008) Traumatic pseudoaneurysm of the superficial temporal artery in a pediatric patient : a case report. J Oral Maxillofac Surg 66: 133-135.

6. Hong JT, Lee SW, Ihn YK, Son BC, Sung JH, et al. (2006) Traumatic pseudo aneurysm of the superficial temporal artery treated by endovascular coil embolization. Surg Neurol 66(1): 86-88.

7. Levisianos I, Sood V (2008) Traumatic aneurysm (pseudo aneurysm) of the superficial temporal artery. Emerg Med J 25(4): 239-240.

8. Fox JT, Cordts PR, Gwinn BC (1994) Traumatic aneurysm of the superficial temporal artery: case report. J Trauma 36(4): 562-564.

9. Bailey IC, Kiryabwire JW (1973) Traumatic aneurysms of the superficial temporal artery. Br J Surg 60: 530-532.

10. Park IH, Kim HS, Park SK, Kim SW (2008) Traumatic Pseudoaneurysm of the Superficial Temporal Artery Diagnosed by 3-dimensional CT Angiography. Journal of Korean Neurosurgical Society 43(4): 209-211.

11. Gull S, Badawy A, Chaudhuri A (2009) The 'pulsatile' sebaceous cyst: beware of a superficial temporal artery aneurysm. BMJ Case Rep 10.1136/bcr.03. 2009.1698. 
This work is licensed under Creative Commons Attribution 4.0 Licens

DOI: 10.19080/JOJCS.2017.02.555596
Your next submission with Juniper Publishers will reach you the below assets

- Quality Editorial service

- Swift Peer Review

- Reprints availability

- E-prints Service

- Manuscript Podcast for convenient understanding

- Global attainment for your research

- Manuscript accessibility in different formats

( Pdf, E-pub, Full Text, Audio)

- Unceasing customer service

Track the below URL for one-step submission https://juniperpublishers.com/online-submission.php 